\title{
Performance Study of Absorption Tower and Adsorption Reactor to Eliminate Ammonia Gas as Pollutant
}

\author{
Ikha Rasti Julia Sari , Januar Arif Fatkhurrahman and Yose Andriani \\ Balai Besar Teknologi Pencegahan Pencemaran Industri (BBTPPI) \\ Jl. Ki Mangunsarkoro No.6 Semarang, Telp. (024) 8310216, 8316315 \\ Email : ikharasti@kemenperin.go.id, ikha.rasti@gmail.com
}

\begin{abstract}
Ammonia known as harmful gas that could impact on health and environment. Typically, ammonia gas emitted by fertilizer industry, rubber factory, etc. There are many options for advance industry to control ammonia gas pollution, absorption tower using water scrubber and using activated carbon as adsorption reaction could be an option. But for middleand lower-class industry, it is common in Indonesia, as seen on many rubber factories, ammonia gas pollution is serious problem to control, actually they have used wet scrubber but eficiency is lower about $47 \%$. This study measure performance for ammonia elimination as gas pollutant using absorption tower and adsorption tower in laboratory scale. Using electrochemical gas sensor, we measure both ammonia concentration for inlet and outlet simultaneously to settle saturation point of these two types of ammonia emission control. In conclusion, Ammonia absorbed in water proportional to saturation time and absorbent volume. Highest absorbed ammonia concentration $1.538 \mathrm{mg} / \mathrm{L}$ on $4000 \mathrm{~mL}$ absorbent. For Adsorption system, saturation time proportional and correlated to adsorbent weight and Adsorption capacity reverse correlated to adsorbent weight. Optimum adsorption point can be achieved from intersection curve between saturation time and adsorption capacity which is 1200 grams adsorbent. Keywords: ammonia, emission control, saturation point, absorption tower, adsorption reactor
\end{abstract}

\section{Introduction}

Ammonia in air was a major pollutant that could impact negative effect for environmental and human health (Behera et al. 2013)(Sundblad et al. 2004)(Aldridge, Tranah, and Shawcross 2015). Typically ammonia gas emitted by fertilizer industry (Goebes, Strader, and Davidson 2003)(Balasubramanian et al. 2015)(Sheppard, Bittman, and Bruulsema 2010), livestock production (Martínez-Lagos et al. n.d.)(Webb et al. 2005)(Muñoz et al. 2016) and rubber industry. Generally, ammonia in industry emitted from raw material and supporting material that contains ammonia on its production process. On crumb rubber industry, ammonia came from raw material that contain protein dan degradated into ammonia (Atagana*, Ejechi, and Ayilumo 1999). Closer look in this industry, commonly they have air pollution control like wetscrubber (Zakeri et al. 2011), but in very low efficiency. Low efficient wet scrubber mean ammonia elimination not yet optimum. Ammonia can be eliminated using both absorption or adsorption system, commonly adsorption can utilize activated carbon and zeolit. Granular activated carbon effectively eliminate polutant like VOCs, toluene and ammonia (Cheng 2008)(Balanay, Bartolucci, and Lungu 2014)(Gonçalves et al. 2011). This is preliminary study in air pollution control in crumb rubber industry, within laboratory scale to study ammonia degradation pattern both in adsorption and absorption system, analyse each efficiency, and determine influenced variables.

\section{Experimental Details}

Main idea of this study is evaluating ammonia air pollution control using adsorption tower and absorption tower in laboratory scale. Ammonia vapour made by diluting $20 \mathrm{~mL} 25 \%$ liquid ammonia into $2000 \mathrm{~mL}$ water. This solution then placed in gas container in room temperature. Ammonia vapour then pumped in stable flow rate, 2 litres per minute for absorption process and 5 litres per minute for adsorption process. Absorption process in this study using $1000 \mathrm{~mL}, 1500 \mathrm{~mL}, 2000 \mathrm{~mL}$, and $4000 \mathrm{~mL}$ absorbent variation, which is water as absorbent. In other process, adsorption process in this study using 
granular activated carbon with weight variation from $500 \mathrm{~g}, 1000 \mathrm{~g}, 1500 \mathrm{~g}$, and $2000 \mathrm{~g}$. Entire system setup shown in figure 1 .

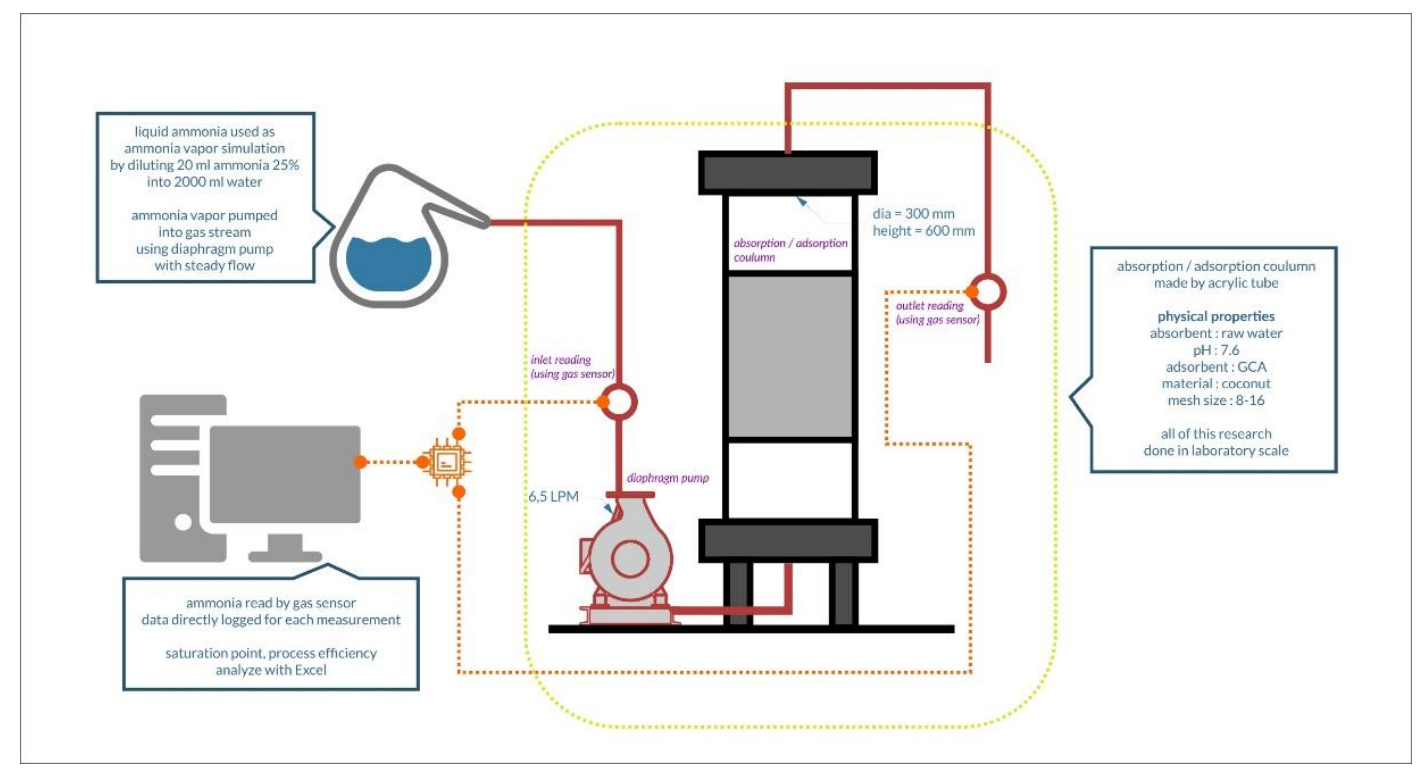

Figure 1. Instrument Setup for Measurement

Inlet and outlet ammonia measured directly using electrochemical based sensor. Each data analyze every 5 minutes average to determine saturation time. Saturation time shown from equilibrium state of inlet concentration and outlet concentration, while absorbed ammonia analyze with standard method.

\section{Result and Discussion}

We conduct four absorbent volume variables for absorption simulation, which is (A) $1000 \mathrm{ml}$, (B) 1500 $\mathrm{ml}$, (C) $2000 \mathrm{ml}$, and (D) $4000 \mathrm{ml}$ Each A, B, C, and D then absorbed with ammonia stream counter current (Wacunzo 2014), from gas container in steady flow 2 LPM. Saturation plot for each absorption process shown in figure 2 .
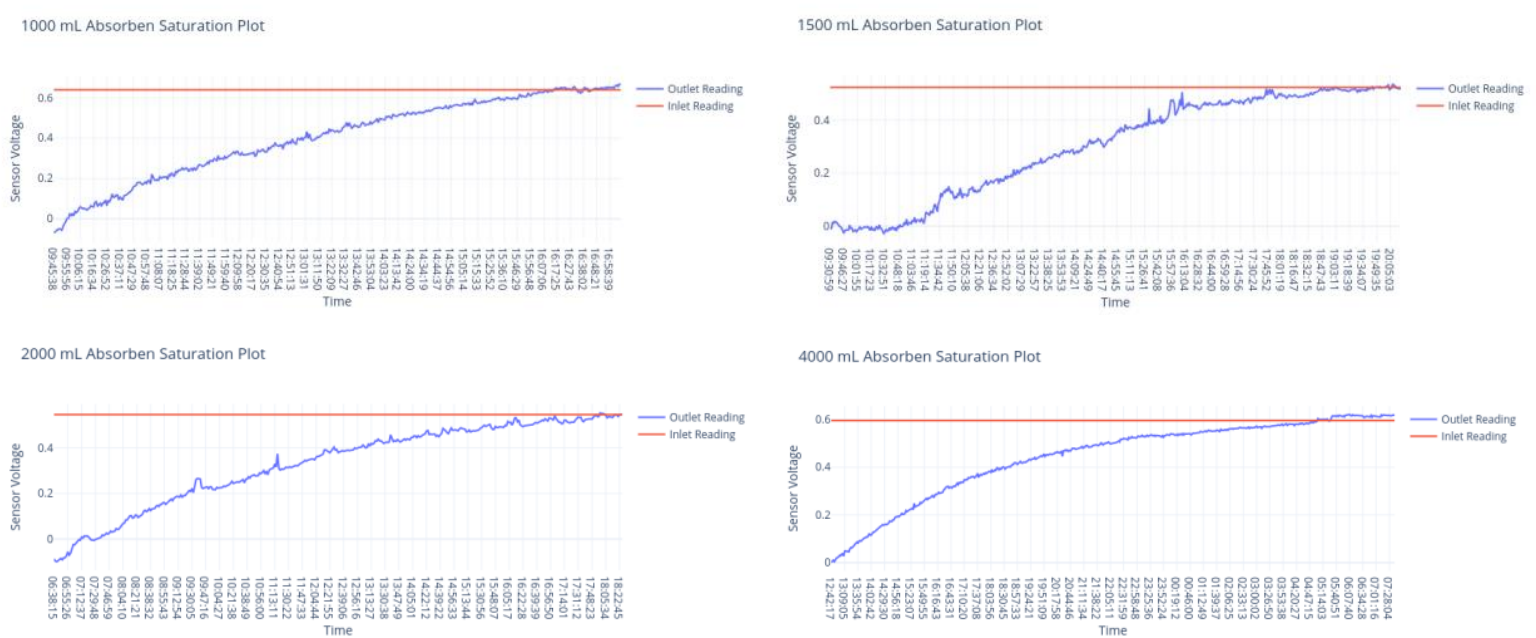

Figure 2. Absorbent Saturation Plot for Each Absorption Process 
Each absorption variation shown different saturation time for ammonia absorption. Higher water as absorbent volume used, the saturation point need longer time. Saturation time also have linear correlation with absorbed ammonia in water, shown in figure 3 below.

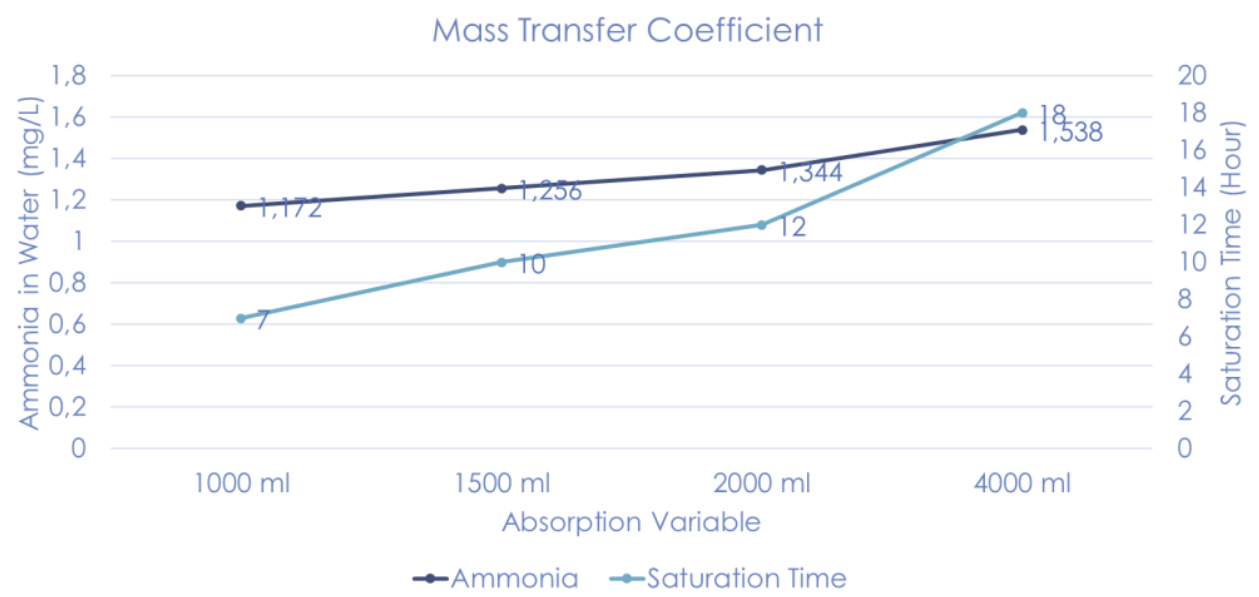

Figure 3. Correlation between Absorbed Ammonia to Saturation Time

We conduct four adsorbent weight based variables for absorption simulation, which is (A) $500 \mathrm{~g}$, (B) $1000 \mathrm{~g}$, (C) $1500 \mathrm{~g}$, and (D) $2000 \mathrm{~g}$. Each A, B, C, and D then adsorbed with ammonia stream from gas container in steady flow 6.5 LPM. Saturation point then evaluated by plotting outlet sensor reading versus sampling time, shown in Figure 4.
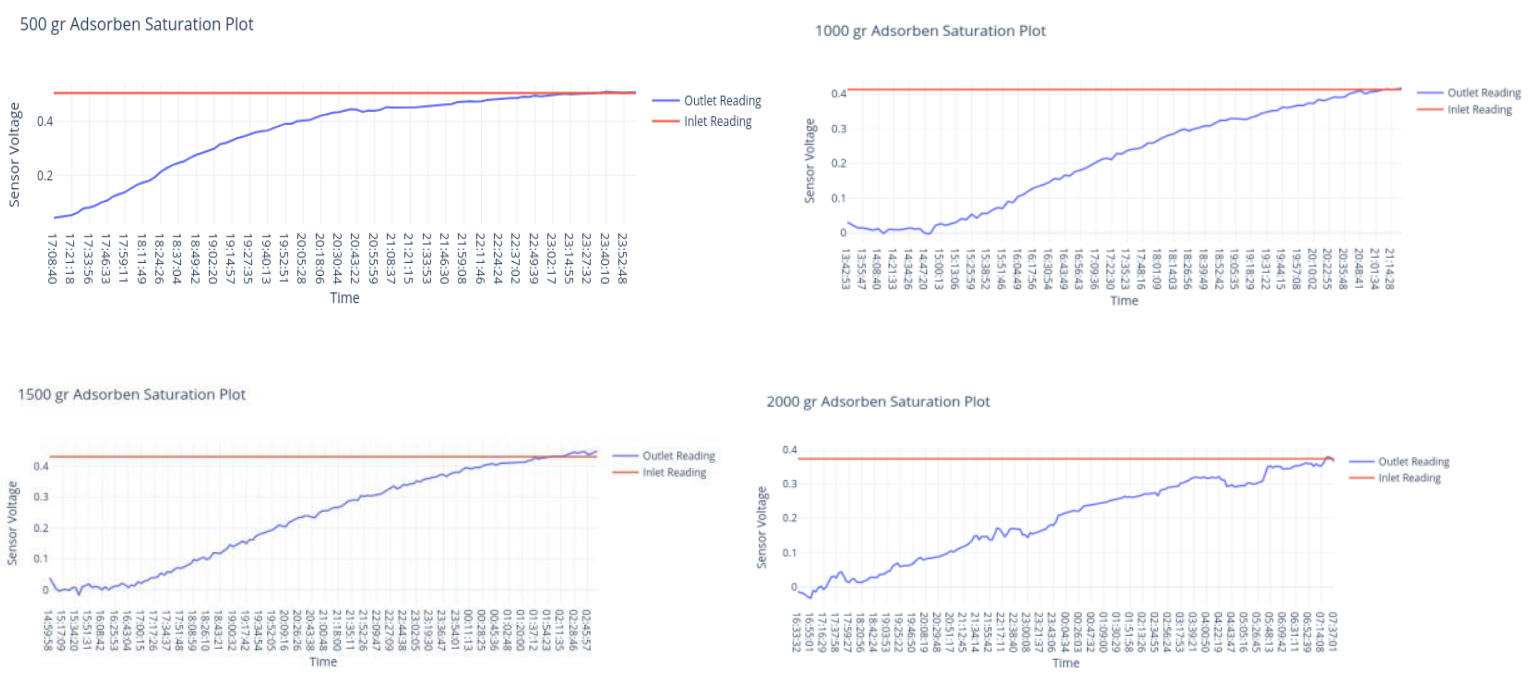

Figure 4. Saturation Time for Each Adsorbent Variation

From figure 4, weight variation of granular activated carbon as adsorbent has interfere saturation time for ammonia elimination. Higher adsorbent weight correlated with longer saturation time. Then, adsorption capacity can be measured with Freunlich equation (Ng et al. 2017) (Desta 2013). This adsorption capacity plot to saturation time can be used to determine optimum adsorption condition, $1200 \mathrm{~g}$. This plot shown in figure 5. 


\section{Adsorption Efficiency Plot}

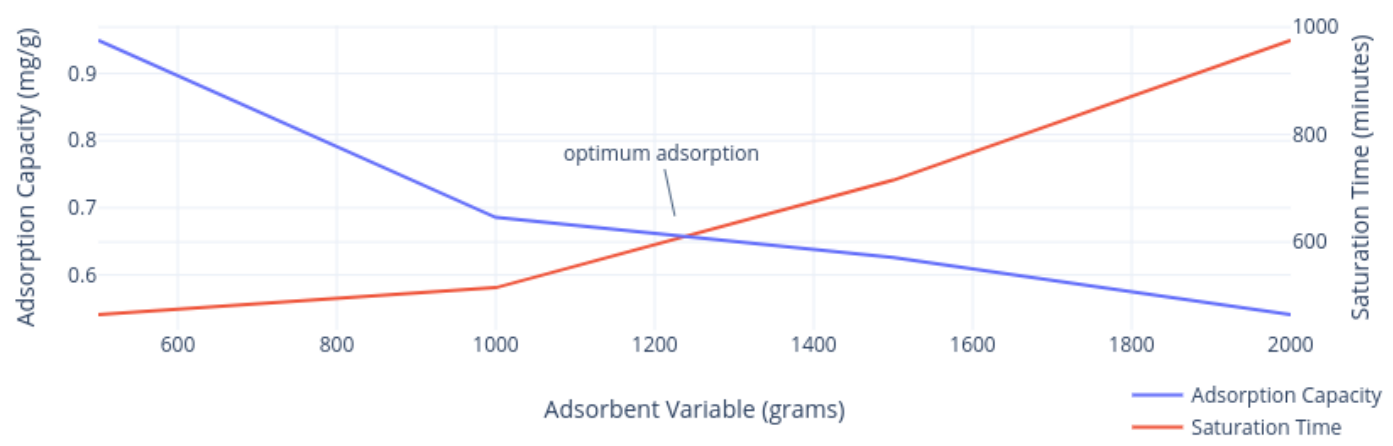

Figure 5. Adsorption Efficiency Plot

In conclusion, Ammonia absorbed in water proportional to saturation time and absorbent volume. Highest absorbed ammonia concentration $1.538 \mathrm{mg} / \mathrm{L}$ on $4000 \mathrm{~mL}$ absorbent. For Adsorption system, Saturation time proportional and correlated to adsorbent weight and Adsorption capacity reverse correlated to adsorbent weight. Optimum adsorption point can be achieve from intersection curve between saturation time and adsorption capacity. It is 1200 grams adsorbent in this experiment

\section{Acknowledgments}

The author express their gratitude to Dr, Ali Murtopo Simbolon, ST, SSi, MM Head of the Center of Industrial Pollution Prevention Technology, Ministry of Industry, for providing necessary facilities.

\section{References}

Aldridge, Dominic R, Edward J Tranah, and Debbie L Shawcross. 2015. "Pathogenesis of Hepatic Encephalopathy: Role of Ammonia and Systemic Inflammation." Journal of Clinical and Experimental Hepatology 5 (Suppl 1): S7-20. https://doi.org/10.1016/j.jceh.2014.06.004.

Atagana*, H. I., B. O. Ejechi, and A. M. Ayilumo. 1999. "Fungi Associated with Degradation of Wastes from Rubber Processing Industry.” Environmental Monitoring and Assessment 55 (3): 401-8. https://doi.org/10.1023/A:1005935032014.

Balanay, Jo Anne G., Alfred A. Bartolucci, and Claudiu T. Lungu. 2014. "Adsorption Characteristics of Activated Carbon Fibers (ACFs) for Toluene: Application in Respiratory Protection." Journal of Occupational and Environmental Hygiene 11 (3): 133-43. https://doi.org/10.1080/15459624.2013.816433.

Balasubramanian, Srinidhi, Sotiria Koloutsou-Vakakis, D. Michael McFarland, and Mark J. Rood. 2015. "Reconsidering Emissions of Ammonia from Chemical Fertilizer Usage in Midwest USA." Journal of Geophysical Study: Atmospheres 120 (12): 6232-46. https://doi.org/10.1002/2015JD023219.

Behera, Sailesh N., Mukesh Sharma, Viney P. Aneja, and Rajasekhar Balasubramanian. 2013. "Ammonia in the Atmosphere: A Review on Emission Sources, Atmospheric Chemistry and Deposition on Terrestrial Bodies." Environmental Science and Pollution Study 20 (11): 80928131. https://doi.org/10.1007/s11356-013-2051-9.

Cheng, Wen-Hsi. 2008. "Adsorption Characteristics of Granular Activated Carbon and SPME Indication of VOCs Breakthrough.” Aerosol and Air Quality Study 8 (2): 178-87. http://aaqr.org/files/article/1285/5_AAQR-08-01-OA-0002_178-187.pdf.

Desta, Mulu Berhe. 2013. "Batch Sorption Experiments: Langmuir and Freundlich Isotherm Studies for the Adsorption of Textile Metal Ions onto Teff Straw ( Eragrostis Tef) Agricultural Waste." Journal of Thermodynamics 2013 (September): 1-6. https://doi.org/10.1155/2013/375830. 
Goebes, Marian Diaz, Ross Strader, and Cliff Davidson. 2003. "An Ammonia Emission Inventory for Fertilizer Application in the United States." Atmospheric Environment 37 (18): 2539-50. https://doi.org/10.1016/S1352-2310(03)00129-8.

Gonçalves, Maraisa, Laura Sánchez-García, Erika de Oliveira Jardim, Joaquín Silvestre-Albero, and Francisco Rodríguez-Reinoso. 2011. "Ammonia Removal Using Activated Carbons: Effect of the Surface Chemistry in Dry and Moist Conditions." Environmental Science \& Technology 45 (24): 10605-10. https://doi.org/10.1021/es203093v.

Martínez-Lagos, Josué, Francisco Salazar, Marta Alfaro, and Tom H Misselbrook. n.d. "Inventory Of Ammonia Emissions From Livestock Production In Los Lagos And Los Ríos Regions, Chile." Chilean Journal Of Agricultural Study. Vol. 70. Accessed May 29, 2019. http://www.bioline.org.br/pdf?cj10010.

Muñoz, E, R Navia, C Zaror, and M Alfaro. 2016. “Ammonia Emissions from Livestock Production in Chile: An Inventory and Uncertainty Analysis." Journal of Soil Science and Plant Nutrition 16 (ahead): 0-0. https://doi.org/10.4067/S0718-95162016005000005.

Ng, Kim Choon, Muhammad Burhan, Muhammad Wakil Shahzad, and Azahar Bin Ismail. 2017. “A Universal Isotherm Model to Capture Adsorption Uptake and Energy Distribution of Porous Heterogeneous Surface." Scientific Reports 7 (1): 10634. https://doi.org/10.1038/s41598-01711156-6.

Sheppard, S C, S. Bittman, and T W Bruulsema. 2010. "Monthly Ammonia Emissions from Fertilizers in 12 Canadian Ecoregions." Canadian Journal of Soil Science 90 (1): 113-27. https://doi.org/10.4141/CJSS09006.

Sundblad, Britt-Marie, Britt-Marie Larsson, Fernado Acevedo, Lena Ernstgård, Gunnar Johanson, Kjell Larsson, and Lena Palmberg. 2004. "Acute Respiratory Effects of Exposure to Ammonia on Healthy Persons." Scandinavian Journal of Work, Environment \& Health 30 (4): 313-21. http://www.ncbi.nlm.nih.gov/pubmed/15458015.

Wacunzo, Arcanjo. 2014. "Chemical Experiment of Ammonia Absorption," no. February 2013: 0-20. https://doi.org/10.13140/2.1.3167.2323.

Webb, J., H. Menzi, B.F. Pain, T.H. Misselbrook, U. Dämmgen, H. Hendriks, and H. Döhler. 2005. "Managing Ammonia Emissions from Livestock Production in Europe." Environmental Pollution 135 (3): 399-406. https://doi.org/10.1016/j.envpol.2004.11.013.

Zakeri, Ali, Aslak Einbu, Per Oscar Wiig, Lars Erik Øi, and Hallvard F. Svendsen. 2011. "Experimental Investigation of Pressure Drop, Liquid Hold-up and Mass Transfer Parameters in a 0.5 m Diameter Absorber Column." Energy Procedia 4: 606-13. https://doi.org/10.1016/j.egypro.2011.01.095. 